\title{
Ex vivo study of use of physiotherapy ultrasound in polymethylmethacrylate beads doped with methylene blue as an antibiotic carrier
}

\section{Estudo ex vivo do uso do ultrassom fisioterapêutico em pérolas de polimetilmetacrilato dopadas com azul de metileno como carreador de antibiótico}

Luigi Milanez Ávila Dias Maciel ${ }^{1}$ (D), Sheila Canevese Rahal ${ }^{1}$ (D) , Alessandra Melchert ${ }^{1}$ (D), Tulio Genari Filho ${ }^{1}$ (D) , Carlos Dias Maciel ${ }^{2}$ (D) , Ivan Felismino Charas dos Santos ${ }^{1 *}$ (D)

'Universidade Estadual Paulista (UNESP), Botucatu, SP, Brazil

2Universidade de São Paulo (USP), São Carlos, SP, Brazil

*Correspondent: ivansantos7@hotmail.com

Received

March 3, 2021

Accepted

June 2, 2021

Published

July 12,2021 .

www.revistas.ufg.br/vet visit the website to get the how to cite in the article page.

\section{Abstract}

Polymethylmethacrylate bone cement is a standard material used as antibiotic carrier in the orthopedic surgery. The ultrasonic energy method is capable of triggering biological effects based on both thermal and non-thermal mechanisms. The aim of the current study is to analyze methylene blue dispersion in polymethylmethacrylate beads, in association with the acoustic field generated by non-thermal ultrasound. Forty-nine specimens were used, and each specimen comprised one polymethylmethacrylate bead $(0.6-\mathrm{mm}$ diameter) doped with methylene blue and deposited in gelatin sample. Forty test specimens were divided into four groups comprising 10 samples, each, based on different ultrasound intensities (Group 1: 1.0 W/cm²; Group 2: 1.5 W/ $\mathrm{cm}^{2}$ ) and polymethylmethacrylate bead depths (A - $2 \mathrm{~cm} ; \mathrm{B}-3$ $\mathrm{cm}$ ) in gelatin sample. The control group comprised other nine specimens and statistically differed from the other groups. All groups irradiated with ultrasound have shown statistically significant differences in methylene blue dispersion, except for Groups $2 \mathrm{~A}$ and 2B. Methylene blue dispersion in gelatin among groups was $1 A>1 B ; 2 A>1 A ; 2 B>1 A ; 2 A>1 B$; and $2 B>1 B$. Low-intensity ultrasound enabled the highest methylene blue dispersion when polymethylmethacrylate bead was positioned superficial; bead depth associated with high-intensity ultrasound did not influence methylene blue dispersion.

Keywords: phonophoresis; non-thermal ultrasound; osteomyelitis; treatment.

\section{Resumo}

O cimento ósseo de polimetilmetacrilato é considerado um material padrão como carreador de antibiótico em cirurgias ortopédicas. A energia ultrassônica é um método capaz de gerar efeitos biológicos por mecanismos térmicos e não 
térmicos. Este estudo teve como objetivo analisar a dispersão de azul de metileno em pérolas de polimetilmetacrilato combinada com a exposição em campo acústico gerado por ultrassom não térmico. Foram utilizados 49 corpos-de-prova, cada um composto por uma pérola de polimetilmetacrilato $(0,6 \mathrm{~mm}$ de diâmetro) dopada com azul de metileno e depositada em amostra de gelatina. Quarenta espécimes foram divididos em quatro grupos de 10 amostras com base nas intensidades de ultrassom (Grupo 1: 1,0 W/cm²; Grupo 2: 1,5 W/cm²) e profundidade $(A-2 \mathrm{~cm} ; \mathrm{B}-3 \mathrm{~cm}$ ) dos grânulos de polimetilmetacrilato na amostra de gelatina. Os outros nove espécimes constituíram o grupo controle. O grupo controle diferiu estatisticamente dos outros grupos. Todos os grupos irradiados com ultrassom apresentaram diferenças significativas, exceto os Grupos 2A e 2B. A dispersão de azul de metileno na gelatina entre os grupos foi: $1 A>1 B ; 2 A>1 A ; 2 B>$ $1 \mathrm{~A} ; 2 \mathrm{~A}>1 \mathrm{~B} ; 2 \mathrm{~B}>1 \mathrm{~B}$. Ultrassom de baixa intensidade permitiu maior dispersão de azul de metileno com polimetilmetacrilato posicionado mais superficialmente, e não ocorreu influência da profundidade da pérola com ultrassom de alta intensidade.

Palavras chave: fonoforese; ultrassom não termal; osteomielite; tratamento.

\section{Introduction}

Different biodegradable or non-biodegradable materials have been used as antibiotic carriers, whereas others remain under investigation ${ }^{(1-5)}$. Local antibiotic carriers should achieve higher concentration than that of systemic administration to maximize their effectiveness and minimize their toxicity, a fact that would help reducing the risk of antibiotic resistance ${ }^{(3)}$.

Polymethylmethacrylate (PMMA) cement is a standard material used as antibiotic carrier in the orthopedic surgery, and enable local delivery of high antibiotic concentrations ${ }^{(2,6)}$. It has been applied in bone defects or joints $(3,4,7)$, besides being used in the form of bone cement, spacer or beads ${ }^{(2,8)}$. This product consists of polymer powder and liquid monomer, which are mixed to form a solid structure ${ }^{(1,8)}$. PMMA powder and antibiotic are mixed and added with liquid monomer to produce handmade beads, and these beads made right after the mix becomes doughy and non-sticky, and threaded onto a steel wire ${ }^{(9)}$.

Some concerns about local PMMA-based antibiotic delivery are based on the assumption that spacer or bead surface may allow biofilm formation and that antibiotic levels may decrease over time ${ }^{(2,4,8)}$. Thus, prolonged sub-therapeutic levels would increase the risk of developing antibiotic-resistant bacteria(6). Furthermore, PMMA is non-resorbable; thus, it requires a second surgical procedure in order to be removed ${ }^{(1,3)}$. Despite controversies, antibiotic-loaded PMMA beads have provided good clinical outcomes in chronic osteomyelitis cases ${ }^{(1,5,6,9)}$. However, many factors may influence antibiotic release from PMMA, such as antibiotic features and cement properties (composition, porosity and monomer amount), among others ${ }^{(1,8)}$. 
The ultrasound waves is capable of triggering biological effects based on both thermal and non-thermal mechanisms ${ }^{(10,11)}$. Thermal methods comprise physical therapy, hyperthermia, high-intensity ultrasound, as well as non-thermal and low-intensity pulsed ultrasound used to stimulate bone-healing fractures ${ }^{(11)}$. Non-thermal and lowintensity pulsed ultrasound therapies lead to uncertain outcomes due to varying mechanisms such as drug delivery based on skin permeabilization processes ${ }^{(11)}$. One of the effects of this mechanism is associated with small particle oscillation due to ultrasound wave movement through different tissues ${ }^{(12)}$. Otherwise, increased skin permeation enabled by non-thermal ultrasound therapies induces microscopic gas bubble formation - i.e., cavitation leading to molecular breakdown at skin layer level, which, in its turn, makes drug penetration through the skin easier ${ }^{(10-12)}$. Continuous-wave ultrasound is recommended for phonophoresis, since it optimizes the ultrasound-drugtissue interaction time, although pulsed ultrasound with fixed frequency is more often used in clinical routine ${ }^{(11,12)}$. Thus, the aim of this study was to analyze methylene blue dispersion in polymethylmethacrylate beads, in association with different ultrasound frequency generated by conventional non-thermal ultrasound equipment. The current hypothesis is that ultrasound can increase the dispersion of the product incorporated to the beads, based on its intensity and bead depth.

\section{Materials and methods}

The study was approved by the Ethics Committee of School of Veterinary Medicine and Animal Science (FMVZ), São Paulo State University (Unesp) (n. 59/2016).

\section{PMMA beads}

Firstly, the silicone (Siloc ${ }^{\circledR}$, ITW Polymers, São Paulo, Brazil) mold was developed by using a Petri dish (23-cm diameter) as mold base; its inner surface was coated with petroleum jelly to avoid adhesion (2,13-15). Silicone was spread onto a Petri dish, and 50 synthetic beads $(0.6-\mathrm{mm}$ diameter) embedded in petroleum jelly were distributed in two dish, 25 beads in two Petri dish in total (Figure 1 and 2).

After the silicone dried (Figure 2), a plastic film soaked in petroleum jelly was placed in the Petri dish, and another silicone layer was applied to the Petri dish. Four nails were used as markers between the two silicone layers.

The second layer was withdrawn after the drying period was over; synthetic beads were removed. Next, PMMA beads were prepared with approximately 5 grams of polymer power to $2.5 \mathrm{~mL}$ liquid monomer (Cimento ósseo Baumer Osteo Class ${ }^{\circledR}$, Baumer, São Paulo, Brazil) (ratio of 2:1) and 0.02 grams of methylene blue were mixed to them. The mix was subjected to polymerization and deposited on the base of the silicone mold. Subsequently, the other part of the mold remained there until final polymerization, which took approximately 10 min. Finally, PMMA beads $(0.6 \mathrm{~mm}$ diameter) doped with methylene blue were removed from the silicone mold(2,15). 


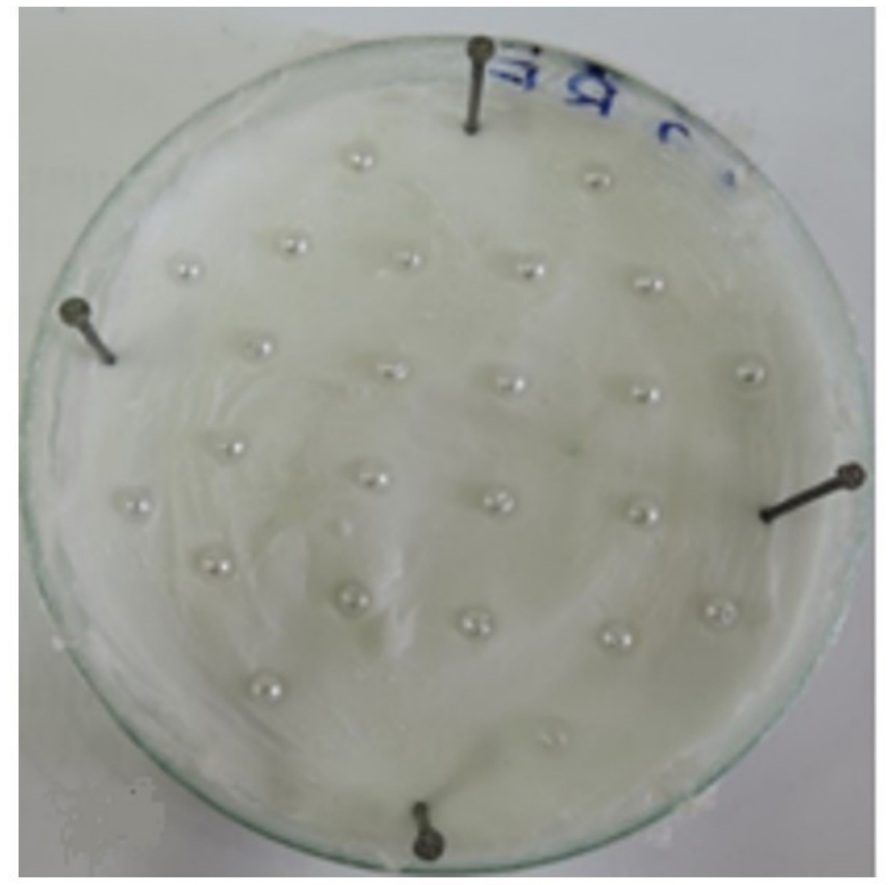

Figure 1. Silicone mold base with synthetic beads (0.6-mm diameter) embedded in petroleum jelly and distributed in Petri dish.

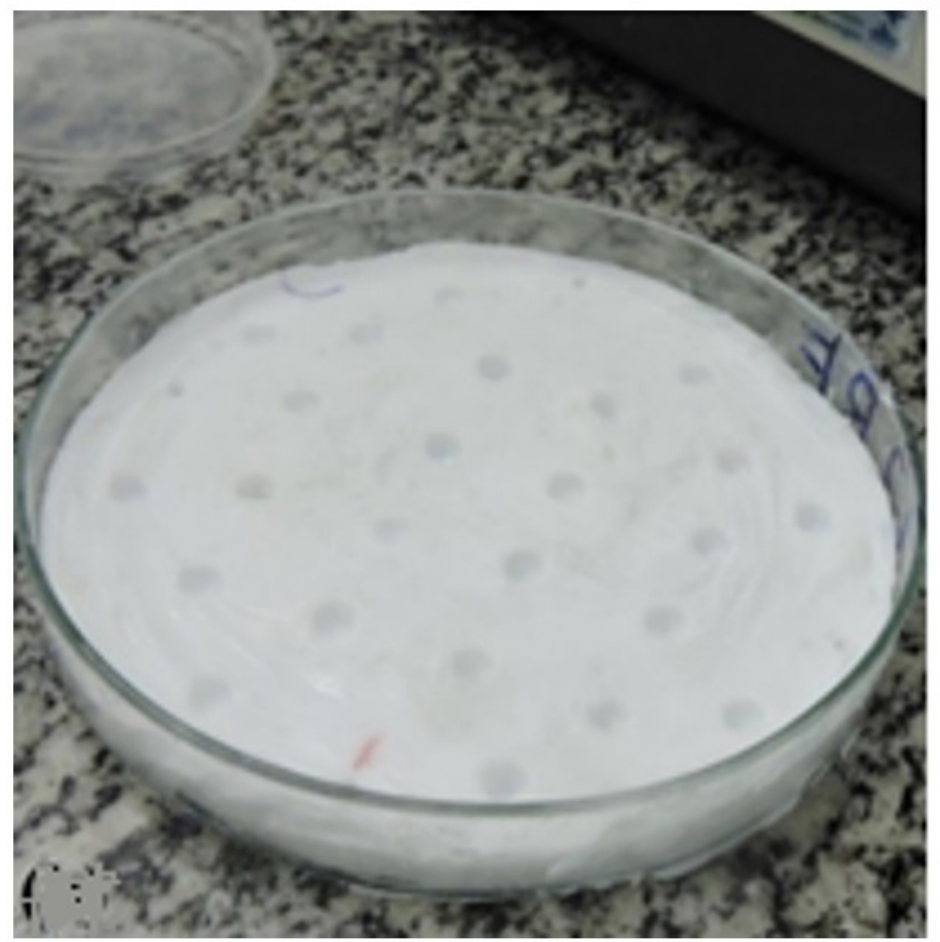

Figure 2. Appearance of silicone mold base after drying. 
Ex vivo study of use of physiotherapy ultrasound in polymethylmethacrylate beads..

Maciel D M A L et al.

\section{Gelatin-based phantoms}

Forty (40) grams of unflavored gelatin powder (Gelatin powder Fleischmann ${ }^{\circledR}$, Fleischmann, São Paulo, Brazil) were added to a beaker filled with $400 \mathrm{~mL}$ of water to form gelatin-based phantoms. The beaker was placed on magnetic stirrer $\left(75^{\circ} \mathrm{C}\right.$ to $85^{\circ}$ C) until getting a homogenous and transparent mix. The mix was distributed into five plastic vials $(180 \mathrm{~mL})$ and left to jellify at room temperature $\left(22^{\circ} \mathrm{C}\right)^{(15)}$.

\section{Specimens}

Each specimen comprised one PMMA bead (0.6-mm diameter) doped with methylene blue and deposited in gelatin sample. A heated spatula ( $5 \mathrm{~mm}$ wide) was used to produce a hole at the center of each gelatin sample at depths of 2 or $3 \mathrm{~cm}$. PMMA bead doped with methylene blue was deposited in the hole, which was covered with gelatin prepared as aforementioned. Specimens $(n=48)$ were kept in refrigerator for $12 \mathrm{~h}$; dispersion tests were carried out at the end of this period.

\section{Dispersion assays}

Forty (40) test specimens were divided into four equal groups, based on different ultrasound intensities (Group 1: $1.0 \mathrm{~W} / \mathrm{cm}^{2}$; Group 2: $1.5 \mathrm{~W} / \mathrm{cm}^{2}$ ) and PMMA bead depths (A - $2 \mathrm{~cm} ; \mathrm{B}-3 \mathrm{~cm}$ ) in gelatin sample (Table I). Eight (8) specimens comprised the control group, which was not irradiated with ultrasound. The control group was added to the experiment in order to check the incidence (or not) of passive methylene blue dispersion from doped beads in the gelling agent ${ }^{(15)}$.

Table I. Groups of test specimens (polymethylmethacrylate beads doped with methylene blue in gelatin samples) for the dispersion assays

\begin{tabular}{cc}
\hline Group 1 $\left(\mathbf{1 . 0} \mathbf{W} / \mathbf{c m}^{2}\right)$ & Group 2 $\left(\mathbf{1 . 5} \mathbf{W} / \mathbf{c m}^{\mathbf{2}}\right)$ \\
\hline Group 1A $(\mathrm{n}=10)-2 \mathrm{~cm}$ deep & Group 2A $(\mathrm{n}=10)-2 \mathrm{~cm}$ deep \\
Group 1B $(\mathrm{n}=10)-3 \mathrm{~cm}$ deep & Group 2B $(\mathrm{n}=10)-3 \mathrm{~cm}$ deep \\
\hline
\end{tabular}

Ultrasound irradiation was carried out in continuous mode, based on stationary application of low-power ultrasound equipment (1 MHz) (Sonacel Expert ${ }^{\circledR}$, Bioset, São Paulo, Brazil) for $5 \mathrm{~min}$. After the ultrasound application was over, specimens were kept in refrigerator $\left(5^{\circ} \mathrm{C}\right)$ for $1 \mathrm{~h}$. Next, samples were removed from the plastic vials, sectioned in half and photographed. Digital photos (Sony Digital Camera ${ }^{\circledR}$, Osaka, Japan) were adjusted to the actual size; methylene blue dispersion was measured with graphical computational tool (Adobe Illustrator ${ }^{\circledR}$, Adobe, Texas, USA).

Statistical analysis

Kolmogorov-Smirnov test was used to evaluate data normality. Subsequently, analysis of variance for independent samples (One way ANOVA) was used to compare groups. Differences were considered significant at $P<0.05$. Statistical analyses were carried out in GraphPad InStat software ('Prism - GraphPad Software ${ }^{\circledR}$, Texas, USA). 


\section{Results}

Complications were not identified throughout the study. Table II describes methylene blue dispersion values based on test specimen and control groups. The control group statistically differed from the other groups when compared the methylene blue dispersion $(P<0.0001)$. All groups irradiated with ultrasound have shown differences, except for Groups 2A and 2B (Table III), and Methylene blue dispersion in gelatin among irradiated groups was $1 \mathrm{~A}>1 \mathrm{~B} ; 2 \mathrm{~A}>1 \mathrm{~A} ; 2 \mathrm{~B}>1 \mathrm{~A} ; 2 \mathrm{~A}>1 \mathrm{~B} ; 2 \mathrm{~B}>1 \mathrm{~B}$.

Table II. Mean values, standard deviations (SD), median and confidence interval (CI) of dispersion values of methylene blue in gelatin samples after irradiation of the ultrasound, based on ultrasound intensity (G1 $\left.-1.0 \mathrm{~W} / \mathrm{cm}^{2} ; \mathrm{G} 2-1.5 \mathrm{~W} / \mathrm{cm}^{2}\right)$ and depth of the polymethylmethacrylate beads $(A-2 \mathrm{~cm} ; B-3 \mathrm{~cm})$, and control group

\begin{tabular}{lccc}
\hline \multicolumn{1}{c}{ Groups } & Mean \pm SD & Median & 95\% CI \\
\hline Group 1A & $4.712 \pm 0.18$ & 4.712 & $4.581-4.844$ \\
Group 1B & $4.268 \pm 0.211$ & 4.275 & $4.117-4.419$ \\
Group 2A & $5.227 \pm 0.250$ & 5.236 & $5.048-5.406$ \\
Group 2B & $5.127 \pm 0.330$ & 5.138 & $4.891-5.363$ \\
Control Group & $3.915 \pm 0.056$ & 3.914 & $3,872-3.958$ \\
\hline
\end{tabular}

Table III. Comparison among groups on dispersion of methylene blue in gelatin samples after irradiation of the ultrasound, according to ultrasound intensity $\left(\mathrm{G} 1-1.0 \mathrm{~W} / \mathrm{cm}^{2} ; \mathrm{G} 2\right.$ $-1.5 \mathrm{~W} / \mathrm{cm}^{2}$ ) and depth of the polymethylmethacrylate beads (A - $2 \mathrm{~cm}$; B $\left.-3 \mathrm{~cm}\right)$, and control group

\begin{tabular}{|c|c|}
\hline Groups & P Value \\
\hline $1 \mathrm{~A}$ versus 1B & $<0.01$ \\
\hline $1 \mathrm{~A}$ versus $2 \mathrm{~A}$ & $<0.001$ \\
\hline $1 \mathrm{~A}$ versus $2 \mathrm{~B}$ & $<0.01$ \\
\hline $1 \mathrm{~B}$ versus $2 \mathrm{~A}$ & $<0.001$ \\
\hline $1 \mathrm{~B}$ versus $2 \mathrm{~B}$ & $<0.001$ \\
\hline $2 \mathrm{~A}$ versus $2 \mathrm{~B}$ & $>0.05$ \\
\hline
\end{tabular}

\section{Discussion}

The current study investigated the potential influence of ultrasound on methylene blue dispersion in PMMA beads in order to use it to increase drug transport, mainly the transport of antibiotics incorporated to dental resin. Furthermore, non-thermal ultrasound has been used as tool to enable transdermal drug delivery, although its 
action mechanism is not yet fully understood(15). The hypothesis of the present study was partly confirmed, since the highest methylene blue dispersion was identified when the polymethylmethacrylate bead was positioned on the most superficial depth and subjected to low-intensity ultrasound. It is worth highlighting that the comparison between Groups 2A and 2B did not show difference in methylene blue dispersion, and it suggested that the PMMA bead position may not have influenced the results when ultrasound was used at its highest intensity $\left(1.5 \mathrm{~W} / \mathrm{cm}^{2}\right)$.

PMMA is a gold standard of constantly high antibiotic delivery in orthopedic infection cases. Although it presents high biocompatibility, it is a non-absorbable material that requires a second surgical procedure in order to be removed ${ }^{(1,2)}$. On the other hand, biodegradable materials such as proteins (e.g., collagen, gelatin, thrombin, and autologous blood clot), bone graft materials (e.g., calcium sulfate and cancellous bone graft) and synthetic polymers (e.g., polylactic acid, polylactide-co-glycolides, polyhydroxyalkanoates, polycaprolactone, polyhydroxybutyrate-co-hydroxyvalerate and cross-linked polydimethylsiloxane) can be considered an alternative antibiotic delivery ${ }^{1,3}$. The main advantage of using biodegradable materials for antibiotic delivery lies on lesser need of bone defect reconstruction. In addition, these materials enable changing variables to accurately release drug amounts over a specific time, they do not spread antibiotics into surrounding tissues and, although they are absorbable materials, they do not allow bacteria to attach to them ${ }^{(1-5)}$. The disadvantage of using these material types is associated with their high cost and with the fact that they were not approved by FDA to be use as antibiotic delivery vehicles ${ }^{(1)}$.

Methylene blue was used as indirect identifier of ultrasound-based drug delivery from PMMA beads; however, further studies are necessary to determine the viability of this method by using antibiotics such as gentamicin. This antibiotic is included in PMMA beads due to its broad-spectrum antimicrobial activity, biocompatibility, water solubility and high thermostability ${ }^{(2,8)}$. The immunoassay method was used to evaluate specimens ( $480 \mathrm{mg}$ of powdered gentamicin sulfate mixed to $40 \mathrm{~g}$ of bone cement) immersed in buffered saline solution for 28 days ${ }^{(17)}$. According to these authors, high amount of antibiotics in the solution was predictable for at least 14 days. Based on this perspective, ultrasound could be used to maintain antibiotic release from the $14^{\text {th }}$ day on in order; however, this hypothesis must be evaluated. Other antibiotics, such as tobramycin and vancomycin, were used in PMMA beads ${ }^{(2)}$, but the influence of ultrasound in these beads must also be assessed.

Gelatin-based phantoms were used in the current study because ultrasound wave propagation speed resembled the propagation speed in soft tissues, without significant wave attenuation, as corroborated in the literature ${ }^{(13,14,18-20)}$. These specimen types, which simulate biological tissues, were often used in ultrasound therapy research due to their acoustic homogeneity, high jellification power at low concentrations, low viscosity, and ultrasound wave propagation speed similar to that observed in biological tissues ${ }^{(13,14)}$. On the other hand, phonophoresis can be influenced by physical permeability promoters such as gel, creams, or hydrocortisone-based compounds ${ }^{(15)}$; silicone appeared to enable low attenuation and ultrasonic transmission power ${ }^{(21)}$. 
According to Benson and McElnay ${ }^{(22)}$, who evaluated several topical products with antiinflammatory effects, ultrasonic transmission capacity is a particular feature of each product's formulation, and it can increase as ultrasonic frequency increases; however, it can change the composition of these products.

PMMA beads used in the current study were standardized in aspects such as composition, homogenization and size, which required the development of a silicone mold. However, PMMA beads prepared by surgeons may show some disadvantages, such as inappropriate antibiotic mixing into the material and beads presenting nonuniform size, which may lead to lower antibiotic availability ${ }^{(2)}$. Ultrasound intensities used in the present study were based on previously reportedresearch about physical parameters of the ultrasonic field in phonophoresis ${ }^{(15)}$. Ultrasound application time was the same for all groups, although there was variation in ultrasound intensity and target depth. Groups subjected to low-intensity ultrasound $\left(1.0 \mathrm{~W} / \mathrm{cm}^{2}\right)$ have shown higher methylene blue dispersion in the superficial PMMA bead (Group 1A) than that observed in the deepest PMMA bead (Group 1B). This outcome represents bias in the clinical context, since low-level antibiotic release may take place in the deepest PMMA beads.

Ultrasound irradiation was continuous and stationary for five minutes in order to minimize likely ultrasonic head overheating, as recommended in the literature ${ }^{(15)}$. Otherwise, variation in ultrasound intensity and frequency does not allow the effective standardization of the technique ${ }^{(2,15)}$. To the best of the current authors' knowledge, no study available in the literature had previously investigated drug penetration depth based on ultrasound; however, according to theoretical postulates about ultrasonic irradiation, the higher the ultrasonic field intensity, the greater its action ${ }^{(20)}$.

The comparison between Groups 1A and 2A has shown that the highest methylene blue dispersion in PMMA beads took place under the highest ultrasound intensity (Group 2A) - both groups presented beads placed in lesser deep layers of gelatin-based phantoms. Based on the comparison between Groups 1A and 2B, the ultrasound used at the highest intensity $\left(1.5 \mathrm{~W} / \mathrm{cm}^{2}\right)$ has also enabled higher methylene blue dispersion, regardless of the PMMA bead depth (2 cm in Group $1 \mathrm{~A}$ and $3 \mathrm{~cm}$ in Group B). The comparison between Groups 1B and 2A has shown that the highest dispersion also took place at the highest ultrasound intensity, although Group 1B's bead was $3 \mathrm{~cm}$ deep and that of Group 2A was $2 \mathrm{~cm}$ deep. The importance of ultrasound intensity was also evident in the comparison between Groups 1B and 2B (both presented bead placed at $3 \mathrm{~cm}$ depth) - the highest dispersion was observed in Group 2B $\left(1.5 \mathrm{~W} / \mathrm{cm}^{2}\right)$. There was statistically significant difference in methylene blue dispersion between the control and the other groups; this outcome has evidenced that the ultrasound has influenced methylene blue dispersion in PMMA beads, as corroborated in the literature ${ }^{(15,16)}$. These authors reported that ultrasound application intensity and time play key role in transdermal delivery. On the other hand, ultrasound intensity must be limited to avoid skin damage. Overall, it can be used at intensity ranging from 0.008 to 50W/ $\mathrm{cm}^{2}(15)$. 


\section{Conclusions}

Low-intensity ultrasound enables the highest methylene blue dispersion when polymethylmethacrylate beads are placed at the most superficial position. In addition, bead depth used in association with high-intensity ultrasound does not influence methylene blue dispersion.

\section{Acknowledgments}

The authors are grateful to CAPES Brazil and CNPq (National Council for Scientific and Technological Development) Brazil (process number: 01585/2017-2).

\section{Conflict of interest}

The authors declare no conflict of interest.

\section{References}

1. Gogia JS, Meehan JP, Di Cesare PE, Jamali AA. Local antibiotic therapy in osteomyelitis. Seminars in Plastic Surgery. 2009. 23(2): 100-107. Disponível em: http://dx.doi.org/10.1055/s-0029-1214162.

2. Gomes D, Pereira M, Bettencourt AF. Osteomyelitis: an overview of antimicrobial therapy. Brazilian Journal of Pharmacology Science. 2013. 49(1): 13-27. Disponível em: http://dx.doi.org/10.1590/S1984$\underline{82502013000100003 .}$

3. Mihok P, Murray J, Williams R. Novel antibiotic delivery and novel antimicrobials in prosthetic joint infection. Journal of Traumatology and Orthopedics. 2016. 4(1): 52-54. Disponível em: http://dx.doi. org/10.82502013000100003.

4. Dorati R, Detrizio A, Modena T, Conti B, Benazzo F, Gastaldi G, GENTA I. Biodegradable scaffolds for bone regeneration combined with drug-delivery systems in osteomyelitis therapy. Pharmacology (Basel). 2017. 10(4): 1-21. Disponível em: http://dx.doi.org/10.3390/ph10040096.

5. Ford CA, Cassat JE. Advances in the local and targeted delivery of anti-infective agents for management of osteomyelitis. Expert Review of Anti-infective Therapy. 2017. 15(9): 851-860. Disponível em: http:// dx.doi.org/10.1080/14787210.2017.1372192.

6. Mclaren AC. Alternative materials to acrylic bone cement for delivery of depot antibiotics in orthopaedic infections. Clinical Orthopaedics and Related Research. 2004. 427: 101-106. Disponível em: http://dx.doi. org/10.1097/01.blo.0000143554.56897.26.

7. Cui Q, Mihalko WM, ShieldsJS, Ries M, Saleh KJ. Antibiotic-impregnated cement spacers for the treatment of infection associated with total hip or knee arthroplasty. Journal of Bone Joint Surgery American. 2007. 89: 871-882. Disponível em: http://dx.doi.org/10.2106/JBJS.E.01070.

8. Magnan B, Bondi M, Maluta T, Samaila E, Schirru L, Dall'Oca C. Acrylic bone cement: current concept review. Musculoskeletal Surgery. 2013. 97: 93-100. Disponível em: http://dx.doi.org/10.1007/s12306013-0293-9.

9. Mohanty SP, Kumar MN, Murthy NS. Use of antibiotic-loaded polymethyl methacrylate beads in the 
Ex vivo study of use of physiotherapy ultrasound in polymethylmethacrylate beads...

Maciel D M A L et al.

management of musculoskeletal sepsis - a retrospective study. Journal of Orthopedic Surgery. 2003. 11(1): 73-79. Disponível em: http://dx.doi.org/10.1177/230949900301100115.

10. Baker KG, Robertson VJ, Duck FA. A review of therapeutic ultrasound: biophysical effects. Physics Therapy. 2001. 81(7): 1351-1358. Disponível em: http://dx.doi.org/10.1093/ptj/81.7.1351.

11. Miller DL, Smith NB, Bailey MR, Czarnota GJ, Hynynen K, Makin IR. Overview of therapeutic ultrasound applications and safety considerations. Journal of Ultrasound Medical. 2012. 31(4): 623-634. Disponível em: https://www.ncbi.nlm.nih.gov/pmc/articles/PMC3810427/.

12. Ter Haar G. Therapeutic ultrasound. European Journal of Ultrasound. 1999. 9:3-9. Disponível em: http://dx.doi.org 10.1016/s0929-8266(99)00013-0.

13. Goldstein A. The effect of acoustic velocity on phantom measurements. Ultrasound Medical Biology. 2000. 26(7): 1133-1143. Disponível em: http://dx.doi.org/10.1016/s0301-5629(00)00248-9.

14. Beard M. Guided wave inspection of embedded cylindrical structures. 2002. Engineering. 11 (2): 233236.

15. Cárnio PB. Variação dos parâmetros físicos do campo ultra-sônico em fonoforese com diclofenaco gel. 2006. 76p. Dissertação (Mestrado em Bioengenharia) - Escola de Engenharia de São Carlos, Faculdade de Medicina de Ribeirão Preto, Instituto de Química de São Carlos, Universidade de São Paulo. Disponível em: http://dx.doi.org/10.11606/D.82.2006.tde-30072007-160907.

16. Escobar-Chávez JJ, Bonilla-Martínez D, Villegas-González MA, Rodríguez-Cruz IM, Domínguez-Delgado $\mathrm{CL}$. The use of sonophoresis in the administration of drugs throughout the skin. Journal of Pharmacology Science. 2009. 12(1): 88-115. Disponível em: http://dx.doi.org/10.18433/J3C30D.

17. Azi ML, Kfuri Junior M, Martinez R, Paccola CAJ. Bone cement and gentamicin in the treatment of bone infection: background and in vitro study. Acta Orthopedics. 2010. 18(1): 31-34. Disponível em: http:// dx.doi.org/10.1590/S1413-78522010000100006.

18. Goldstein A. The effect of acoustic velocity on phantom measurements. Ultrasound in Medicine and Biology. 2000. 26(7): 1133-1143. Disponível em: http://dx.doi.org/10.1016/s0301-5629(00)00248-9.

19. Culjat MO, Goldenberg D, Tewari P, Singh RS. A review of tissue substitutes for ultrasound imaging. Ultrasound Medice and Biology. 2010. 36(6): 861-873. Disponível em: http://dx.doi.org/10.1016/j. ultrasmedbio.2010.02.012.

20. Low L, Reed A. Eletroterapia explicada: princípios e prática. 2001. 3 ed. São Paulo, Manole, 131p.

21. Balmaseda Junior MT, Fatehi MT, Koozekanani SH, Lee AL. Ultrasound therapy: a comparative study of different coupling media. 1986. Archive of Physic and Medice Rehabilitation. 67: e14750. Disponível em: http://dx.doi.org/10.1016/0003-9993(86)90052-3.

22. Benson HAE, McElnay JC. Topical non-steroidal anti-inflammatory products as ultrasound couplants: their potential in phonophoresis. 1994. Physiotherapy. 80(2): 74-76. Disponível em: http://dx.doi.org/ 10.1016/S0031-9406(10)61010-3. 